\title{
Fire resistance of timbers from tropical countries and comparison of experimental charring rates with various models
}

Jacques Michel Njankouo, Jean-Claude Dotreppe, Jean-Marc Franssen

Department of Mechanics of materials and Structures, University of Liege, 1 Chemin des chevreuils, B-4000 Liege 1, Belgium

\begin{abstract}
Tropical hardwood species are more and more used in the field of construction due to the particular qualities they can offer. Presently it is no longer possible to envisage the development of construction materials and products without taking into consideration the problem of their fire behaviour, and more particularly of their fire resistance. In the case of timber elements, this characteristic is mainly influenced by the charring rate of the external layers of the element. On the other hand this parameter is influenced by the density of the material.

Limited information is available on the charring rate of tropical hardwood species. Therefore experimental investigations have been conducted at the University of Liege to study this characteristic. Seven tropical and three timber species from temperate countries have been examined. Two types of test have been used, one on small specimens, the other on a construction element made of one single material. In the first type, 20 specimens have been manufactured by gluing several laminates together. The specimens were instrumented with four thermocouples inserted at various depths in four different laminates. In the second type, a non-loaded wall made of 12 glued-laminated spruce beam profiles was instrumented with thermocouples embedded at different depths in the panel for the evaluation of the charring rate.

Experimental charring rates have been compared with the results derived from Eurocode EC5-1.2

recommendation [ENV 1995-1-2. Eurocode 5: Design of timber structures - Part 1-2: General rules - Structural fire design. European prestandard; 1994], Australian standard AS 1720.4 relation [AS 1720.4. Timber structures Part 4: fire resistance of structural timber members. North Sydney, Australia: Standards Australia; 1990] and White's model [Charring rates of different wood species. PhD dissertation. Madison University of Wisconsin, Madison, WI, 1988; White RH, Erik V, Nordheim EV. Charring rate of wood for ASTM E119 exposure. Fire Technol 1992;28(1)]. This comparison shows that the results obtained from these three models are not entirely satisfactory for tropical hardwood species. Therefore a new model has been proposed.
\end{abstract}

Keywords: Timber; Tropical hardwood; Fire test; Fire resistance; Modelling; Charring rate

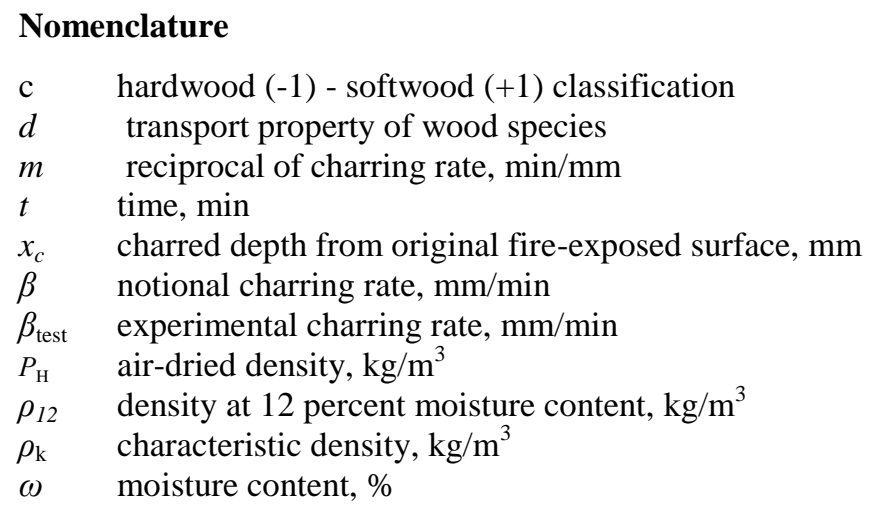

\section{Introduction}

In Belgium, wood is widely available. More particularly, in Wallonia, the southern part of Belgium, wood is of excellent quality for building purposes. However hardly $8 \%$ of the Belgian building patrimony is realized with this material, while in other continents or countries such as North America, Scandinavian countries, New Zealand, Germany and Switzerland, timber is used extensively in the field of construction. The main reasons for this low use are related to building tradition and also to some lack of confidence in the performance and durability of timber construction, which is very often groundless. 
Despite the good quality of Belgian wood, tropical hardwood species are frequently being used in Belgium and in Europe for the particular qualities they can offer.

It is presently no longer possible to envisage the development of construction materials and products without taking into consideration the problem of their fire behaviour, and more particularly of their fire resistance.

Timber is an inflammable and combustible material, but its fire resistance characteristics are considered to be satisfactory. In fact during the exposure to fire a charred layer forms on the external part of the timber element, that protects the underlying layers against the action of the fire. Therefore the residual section of the beam or of the column decreases slowly and the element loses only very progressively its structural capacity. The main parameter in the study of the fire resistance of timber structural elements is therefore their charring rate. This parameter is influenced mainly by the density of the material. Other factors have also an influence on the charring rate such as, for example, the moisture content. This factor has not been considered here because the moisture content was very similar in all specimens. Except for one specimen, the moisture content varied between $9 \%$ and $13 \%$, i.e., very close to the value of $12 \%$ that is usually considered as the standard condition for testing mechanical properties of wood. This value of $12 \%$ also corresponds to the moisture content in timber members that are classified in Service Class 1 according to Eurocode 5, i.e., timber members located in a dry environment such as the interior of a building construction.

The main purpose of this research study is to analyse the charring rate of various timber species submitted to a standard fire [1,2], more particularly of tropical hardwood species, and to recommend a model to assess this characteristic in relation to the density of the material.

As there is limited information available on the charring rate of tropical hardwood, it has been decided to perform experimental investigations at the University of Liege to study this characteristic. Two types of test have been used. The first procedure has been developed at the University of Liege. Specimens have been manufactured by gluing several laminates together and instrumented with thermocouples inserted at various depths in different laminates. The second test consisted of a fire resistance test performed on a full scale nonloaded wall made of spruce. The wall has been instrumented with thermocouples embedded at different depths in the panel for the evaluation of the charring rate.

In order to make a proposal for the charring rate, these experimental results have to be compared with values recommended in various standards like EC5 [3] and those obtained from empirical models. This comparison will show if these models are appropriate for design purposes when tropical hardwood species are used. If not, a new model will be proposed.

\section{Literature background}

The charring rate of both softwood or hardwood timber exposed to the standard time-temperature curve [1,2] has been studied in United States [4-6], Sweden [7], Australia [8], New Zealand [9] and Malaysia [10]. All these investigations show that the density of wood has a major influence on this characteristic but tropical species have hardly been considered in these research works.

It is known that, due to the lack of a standard test procedure for determining charring rates, the results found in the literature may have been obtained in different ways. König and Waleij [7], for example, proposed to define a basic charring rate as the charring rate corresponding to one-dimensional heat transfer conditions.

Several empirical models have been developed [4-6]. One of these and two methods proposed in standards currently used for fire design of timber construction have been compared with the experimental results obtained in this study.

\subsection{Eurocode 5 recommendation}

EC5 assumes that the charring rate of timber made of solid or glued-laminated hardwood decreases linearly with density, with a limit of $0.5 \mathrm{~mm} / \mathrm{min}$ for density larger than $450 \mathrm{~kg} / \mathrm{m}^{3}$ (see Table 1). For softwood species the standard provides a mean value of $0.7 \mathrm{~mm} / \mathrm{min}$ for density larger than $290 \mathrm{~kg} / \mathrm{m}^{3}$. 


\subsection{Australian standard model}

The Australian code AS 1720.4 [11] gives the following equation for the notional charring rate $\beta(\mathrm{mm} / \mathrm{min}) \mathrm{as}$ a function of wood density:

$\beta=0.4+\left(\frac{280}{\rho_{12}}\right)^{2}$

where $\rho_{12}$ is the wood density at $12 \%$ moisture content $\left(\mathrm{kg} / \mathrm{m}^{3}\right)$.

When determining the remaining effective residual section for structural purposes, both standards EC5 and AS 1720.4 calculate an effective charred depth by adding a constant thickness of $7 \mathrm{~mm}$ to the calculated value in order to take into account the heat-affected zone.

Table 1: Notional charring rates of timbers for various standards

\begin{tabular}{|c|c|c|}
\hline Standard/timber species & $\begin{array}{l}\text { Density } \\
\left(\mathrm{kg} / \mathrm{m}^{3}\right)\end{array}$ & $\begin{array}{c}\text { Charring rate } \\
(\mathrm{mm} / \mathrm{min})\end{array}$ \\
\hline \multicolumn{3}{|l|}{$E C 5^{a}[3]$} \\
\hline Glued-laminated softwood & 290 & 0.70 \\
\hline Solid or glued-laminated hardwood & 290 & 0.70 \\
\hline Solid or glued-laminated hardwood & 450 & 0.50 \\
\hline \multicolumn{3}{|l|}{ British standard BS 5268 [10] } \\
\hline Hardwood $^{\mathrm{b}}$ & & 0.50 \\
\hline \multicolumn{3}{|l|}{ Forest Research Institute Malaysia [10] } \\
\hline Balau (Shorea spp.) & & 0.30 \\
\hline Merbau (Intsia palembanica) & & 0.33 \\
\hline
\end{tabular}

${ }^{a}$ Minimum density or characteristic density of species.

${ }^{\mathrm{b}}$ Oak, utile, keruing, teak, greenback, jarrah.

Table 2: Transport property for species used in this study (suggested by White)

\begin{tabular}{lc}
\hline \multicolumn{1}{c}{ Species } & Estimate for $\boldsymbol{d}$ \\
\hline Spruce (Pinus sylvestris) & 36 \\
Fir (Abies alba) & 3 \\
Oak (Quercus robur) & 3 \\
Azobe (Lophira alata) & 3 \\
Afzelia (Afzelia bipindensis) & 3 \\
Balau (Shorea spp.) & 3 \\
Bilinga (Nauclea diderrichi) & 25 \\
Meranti (Shorea rubra) & 14 \\
Merbau (Intsia) & 3 \\
Wenge (Millettia laurentti) & 3 \\
\hline
\end{tabular}

\subsection{White's model}

White and coworkers [5,6] developed an empirical model for the charring rate based on four tests on hardwood species with extensive sets of specimens. Species were hard maple (Acer sp.), yellow-poplar (Liriodendron tulipera), red oak (Quercus sp.) and basswood (Tilia sp.). The following non-linear relation was proposed:

$$
t=h x_{\mathrm{c}}^{1.23}
$$


where $t$ is the time $(\mathrm{min}), x_{c}$ is the charred depth from original fire-exposed surface $(\mathrm{mm}), h$ is calculated according to Eq. (3), used for both hardwood and softwood species $\left(\mathrm{min} / \mathrm{mm}^{1.23}\right)$,

$$
\begin{aligned}
\ln (h)= & 1.3349 \rho-0.009887 \rho d+0.1176 c \\
& -0.003887 c d+0.01717 \omega-1.2521,
\end{aligned}
$$

where $c$ is the wood species classification (-): (-1) for hardwood and (+1) for softwood, $d$ is the transport property of wood species (-) including longitudinal gas permeability, treatability, and diffusion coefficients, see Table 2, $p$ is the density of the wood $\left(\mathrm{kg} / \mathrm{m}^{3}\right), \omega$ is the moisture content $(\%)$.

\section{Tests performed at the University of Liege}

Two experimental procedures have been conducted in Liege using a small vertical furnace $(2 \mathrm{~m} \times 2 \mathrm{~m})$. They were performed in accordance with the recommendations of the Belgian standard for fire resistance of building elements NBN 713-020 [13], including a pressure difference of $20 \mathrm{~Pa}$ applied between the inside of the furnace and the environment.

\subsection{Test 1: charring rate of timber specimens}

The Belgian standard gives only general indications regarding the test set-ups. Therefore, a test set-up has been designed at the University of Liege to investigate the charring rate of tropical hardwood (Fig. 1). In this set up, one wall of the furnace is made of a steel frame filled with cellular concrete blocks. Twenty holes measuring 280 $\times 170 \mathrm{~mm}$ have been made in the concrete wall for the placing of specimens as well as their fixing with insulating material.

The tested specimens are submitted on one side to the ISO 834 standard fire curve [1].

Twenty specimens from seven tropical species with density ranging from $500 \mathrm{~kg} / \mathrm{m}^{3}$ for meranti to $1000 \mathrm{~kg} / \mathrm{m}^{3}$ for azobe and three species from temperate countries (oak, fir, spruce) were selected for this test.

Fig. 1. Sample holder and specimens for test 1 .

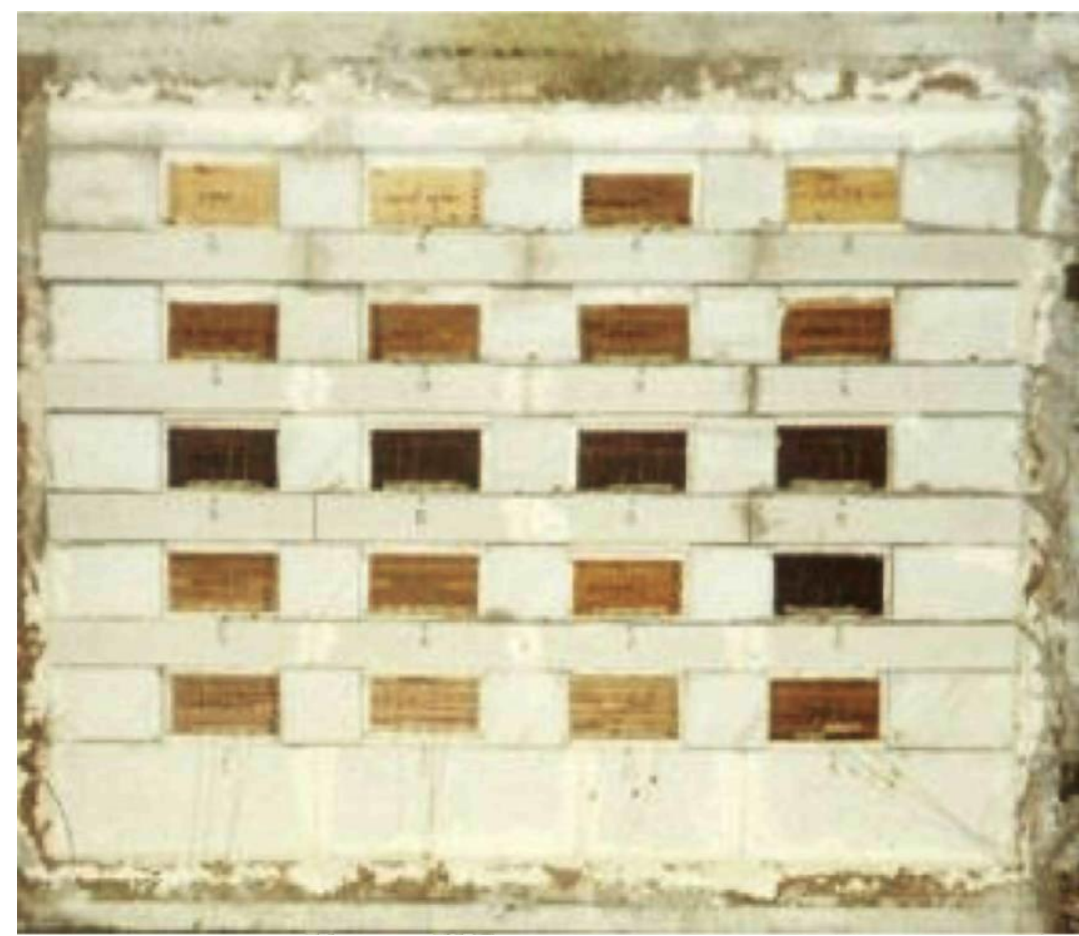


The specimens comprised eighteen $250 \times 140 \times 90 \mathrm{~mm}$ specimens manufactured by gluing seven $20 \mathrm{~mm}$ thick laminates together, one specimen made of three laminates for wenge species and one solid specimen for spruce species. Specimens were maintained tightly in the holes of the concrete wall by means of rigid insulation and by fitting all around with ceramic fibre.

Temperature measurements were taken by means of four thermocouples inserted at different depths in four different laminates situated in the middle part of each specimen.

Traditionally and in the procedure used here, it is assumed that the charring front reaches a thermocouple when its temperature indicates $300{ }^{\circ} \mathrm{C}$, assuming that ignition starts at this point. The test is therefore completed when all thermocouples have reached a temperature of $300{ }^{\circ} \mathrm{C}$.

\subsection{Test 2: fire resistance of a wall}

A non-loaded wall with nominal dimensions $86 \mathrm{~mm}$ thick, $1640 \mathrm{~mm}$ high and $2170 \mathrm{~mm}$ wide, manufactured by embedding twelve glued-laminated spruce beam profiles, was erected and subjected to fire exposure on one side. Fig. 2 shows the technical details of the beams used for the realisation of the wall.

The density of the spruce was $434 \mathrm{~kg} / \mathrm{m}^{3}$. The mean moisture content obtained by using a resistive device in three different beams situated at three different levels of the wall was $13.9 \%$.

The wall was instrumented with thermocouples located both on the non-exposed surface and at different depths from this surface in various elements in the wall (see Figs. 2 and 3).

Fig. 2. Technical details of the tested wall.

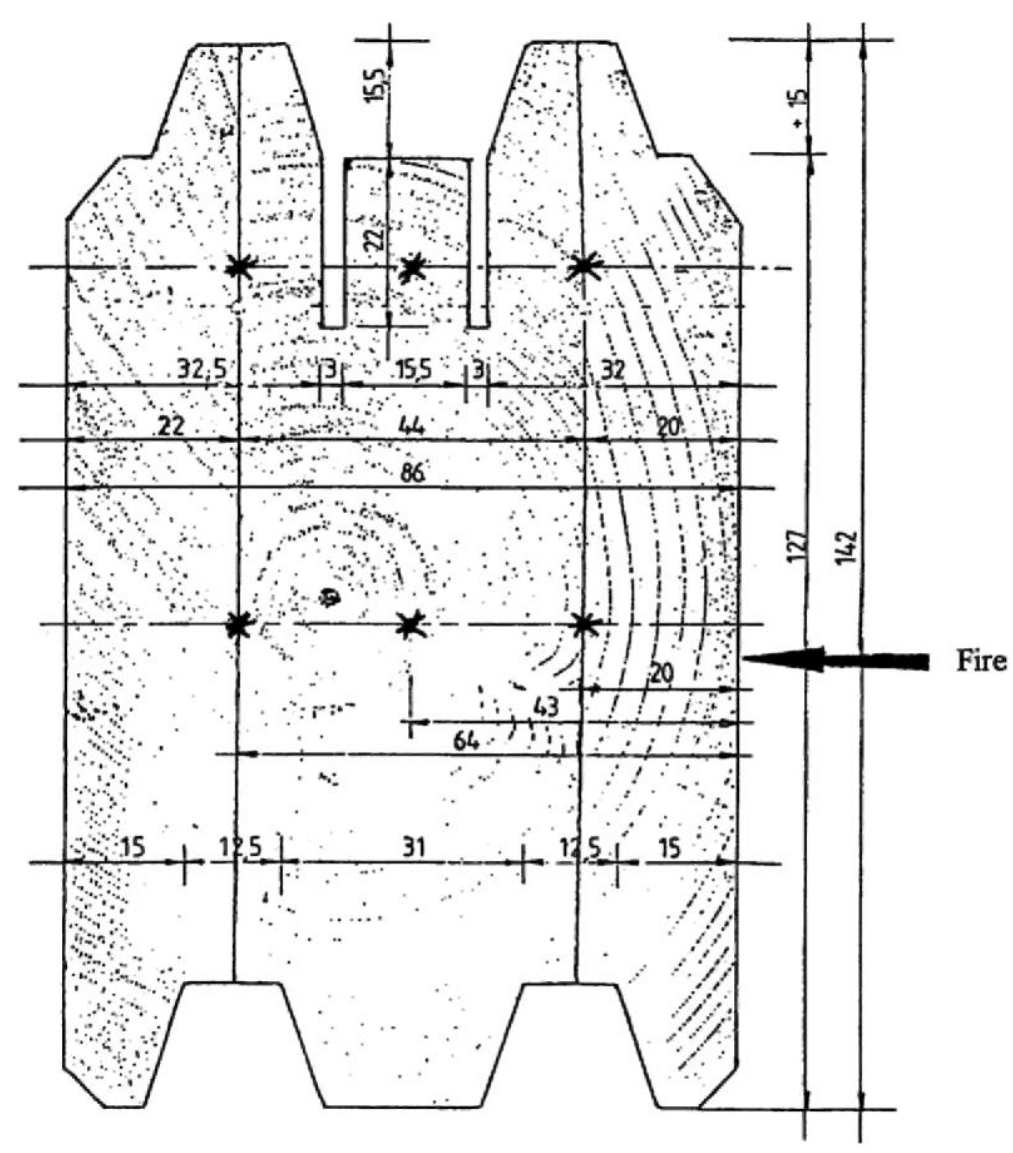




\section{Experimental procedure for determining the charring rates}

\subsection{Test 1: specimens}

For each tested specimen, four pairs of time and charred depth have been recorded. A charred depth proportional to time was considered with the following time-location relation

$$
t=m x_{\mathrm{c}}
$$

Values for the parameter $m$ have been obtained by linear regression of the time location data. Regressions have been made with time $(t)$ as the dependent variable and the charred depth $\left(x_{c}\right)$ as the independent variable. This is consistent with the experiments in which times corresponding to the $300{ }^{\circ} \mathrm{C}$ criterion were measured for fixed thermocouple locations.

The experimental charring rate $\beta_{\text {test }}$ as it is normally considered ( $\left.\mathrm{mm} / \mathrm{min}\right)$ is simply the inverse of $m$.

The physical characteristics of the specimens and the experimental results (charring rates) are presented in Table 3. They are discussed in Section 5.

\subsection{Test 2: wall}

The same procedure has been used to evaluate the charring rate of the spruce wall. The temperature-time curves drawn for the various thermocouples embedded in the wall together with their location provide the following linear regression equation:

$$
t=1.9443 x_{\mathrm{c}}
$$

The inverse of the constant gives the experimental charring rate $\beta_{\text {test }}=0.51 \mathrm{~mm} / \mathrm{min}$.

The fire resistance test performed on the wall has also been analysed to obtain a second rough estimate of the charring rate. The mean depth of the residual thickness of the panel has been measured after the test thus giving the mean charred depth. Using the fire resistance duration the following estimated value has been obtained : $\beta^{*}$ test $=0.64 \mathrm{~mm} / \mathrm{min}$. This is in fact the most simple procedure (visual damage) to determine charring rates experimentally. It can be observed that the difference between both methods is significant.

\section{Comparison with various models and presentation of a new proposal}

\subsection{Eurocode 5 EC5-1.2}

Experimental results have been compared with the notional charring rate values proposed in EC5. A separate comparison has been made for softwood and hardwood species.

Fig. 4 presents the results of softwood species specimens and shows that for the two types of tests, the EC5 recommendation is generally on the safe side, with only one result very slightly on the unsafe side.

The results for tropical hardwood species are presented in Fig. 5. It can be seen that for densities between 500 and $800 \mathrm{~kg} / \mathrm{m}^{3}$, EC5 recommendation is unsafe, while it is safe for densities between 800 and $1100 \mathrm{~kg} / \mathrm{m}^{3}$.

\subsection{Australian standard AS 1720.4}

As the Australian code [11] provides a notional charring rate depending on the wood density only (cf. Eq. (1)), it is easy to make the same type of comparison for tropical hardwood species. This is presented in Fig. 6.

Almost all experimental results are on the safe side, with a difference with the values of the model larger than $15 \%$ for many of them, suggesting that the model is conservative.

Fig. 7 is another way of presenting the comparison, also confirming that the model is conservative. 
Fig. 3. Test set-up for the wall (test 2).

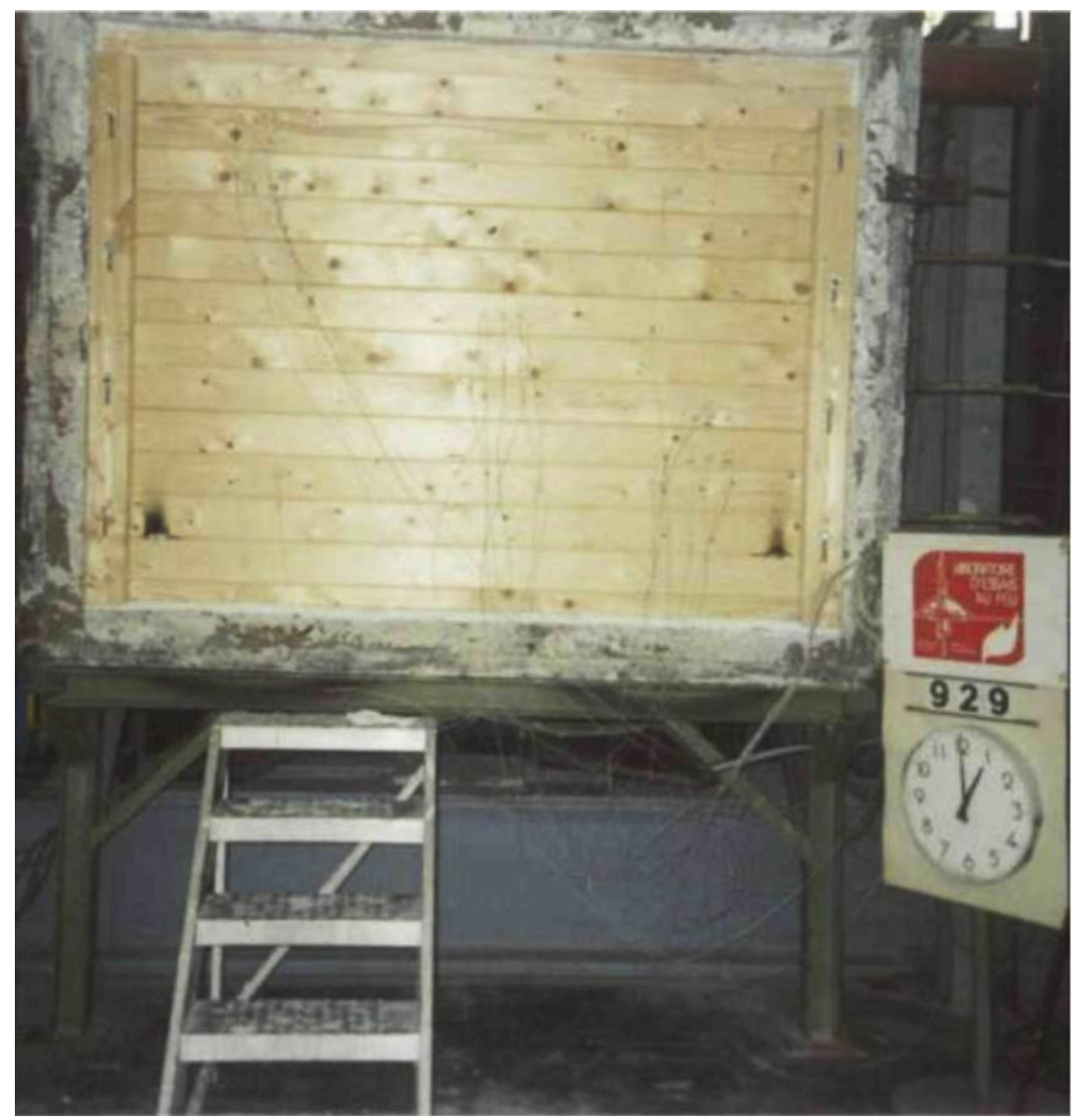

Table 3 : Charring rate results

\begin{tabular}{llccccc}
\hline No. Specimen & $\begin{array}{c}\text { Moisture } \\
\text { content }(\boldsymbol{\%})\end{array}$ & $\begin{array}{c}\text { Density } \\
\left(\mathbf{k g} / \mathbf{m}^{\mathbf{3}}\right)\end{array}$ & $\begin{array}{c}\text { Experimental } \\
\text { charring rate } \\
(\mathbf{m m} / \mathbf{m i n})\end{array}$ & $\begin{array}{c}\text { White's model } \\
\text { charring rate } \\
(\mathbf{m m} / \mathbf{m i n})\end{array}$ & $\begin{array}{c}\text { ULg model } \\
\text { charring rate } \\
(\mathbf{m m} / \mathbf{m i n})\end{array}$ \\
\hline 1. & Fir & 13 & 421 & 0.71 & 0.61 & $(0.63)$ \\
2. & Sprucel & 9 & 480 & 0.62 & 0.86 & $(0.61)$ \\
3. & Spruce2 & 9 & 476 & 0.57 & 0.84 & $(0.61)$ \\
4. & Oak & 10 & 557 & 0.59 & 0.53 & $(0.58)$ \\
5. & Merantil & 10 & 522 & 0.54 & 0.72 & 0.59 \\
6. & Meranti2 & 10 & 522 & 0.55 & 0.71 & 0.59 \\
7. & Bilinga & 11 & 692 & 0.58 & 0.57 & 0.54 \\
8. & Merbau & 12 & 779 & 0.50 & 0.53 & 0.51 \\
9. & Afzelial & 13 & 863 & 0.36 & 0.49 & 0.48 \\
10. Afzelia2 & 13 & 836 & 0.43 & 0.49 & 0.49 \\
11. Afzelia3 & 11 & 833 & 0.49 & 0.49 & 0.59 \\
12. Afzelia4 & 12 & 800 & 0.51 & 0.51 & 0.44 \\
13. Afzelia5 & 20 & 968 & 0.37 & 0.29 & 0.46 \\
14. Wenge & 13 & 923 & 0.49 & 0.48 & 0.45 \\
15. Balaul & 9 & 939 & 0.40 & 0.46 & 0.44 \\
16. Balau2 & 9 & 984 & 0.41 & 0.39 & 0.42 \\
17. Azobel & 13 & 1050 & 0.41 & 0.42 & 0.42 \\
18. Azobe2 & 13 & 1040 & 0.41 & 0.43 & 0.43 \\
19. Azobe3 & 13 & 1000 & 0.41 & 0.40 & 0.41 \\
20. Azobe4 & 13 & 1060 & 0.47 & & \\
\hline
\end{tabular}


Published in: Construction and Building Materials (2005), vol. 19, iss. 5, pp. 376-386 Status : Postprint (Author's version)

Fig. 4. Comparison of test results with Eurocode 5 for softwood species.

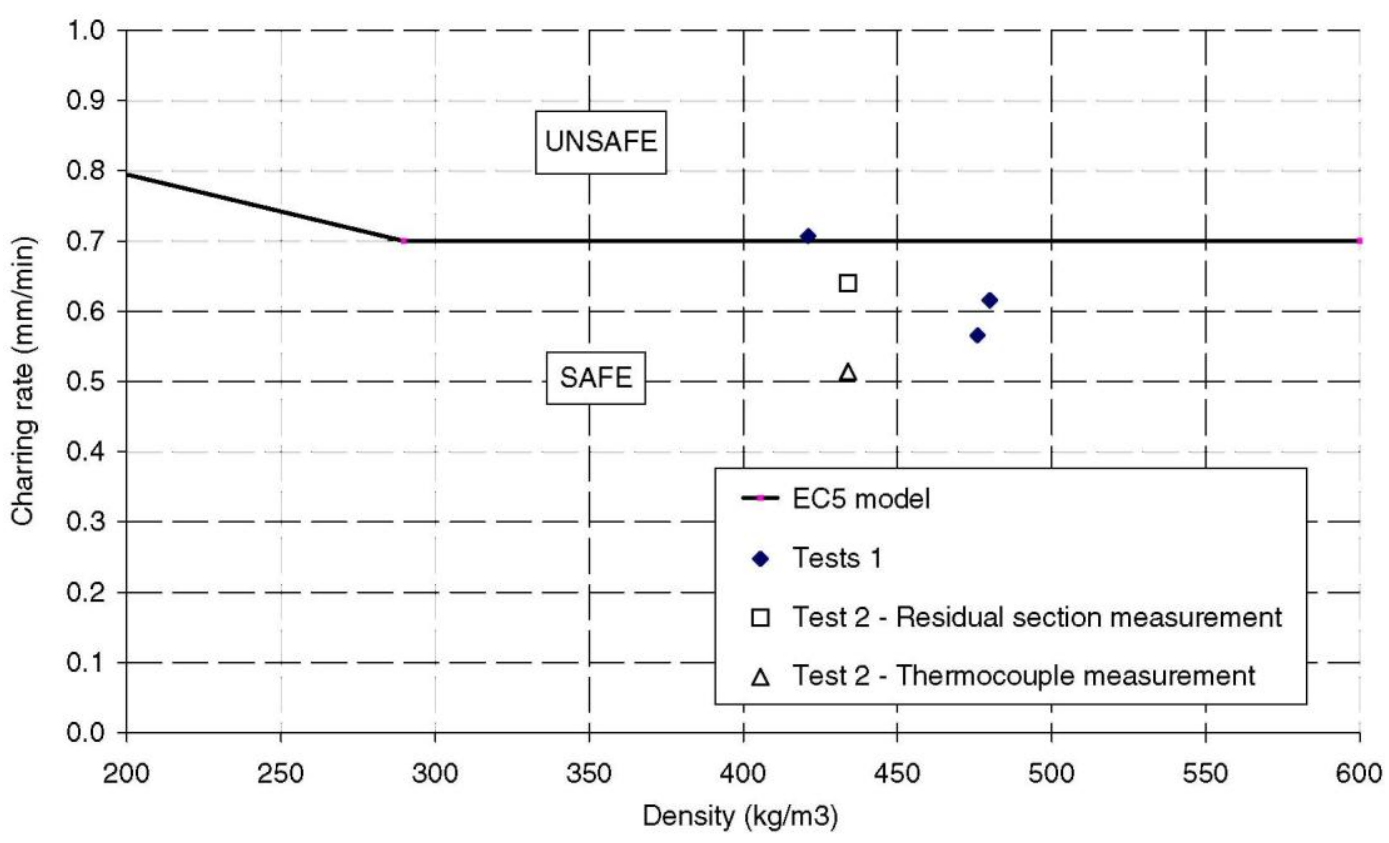

Fig. 5. Comparison of test results with Eurocode 5 for tropical species.

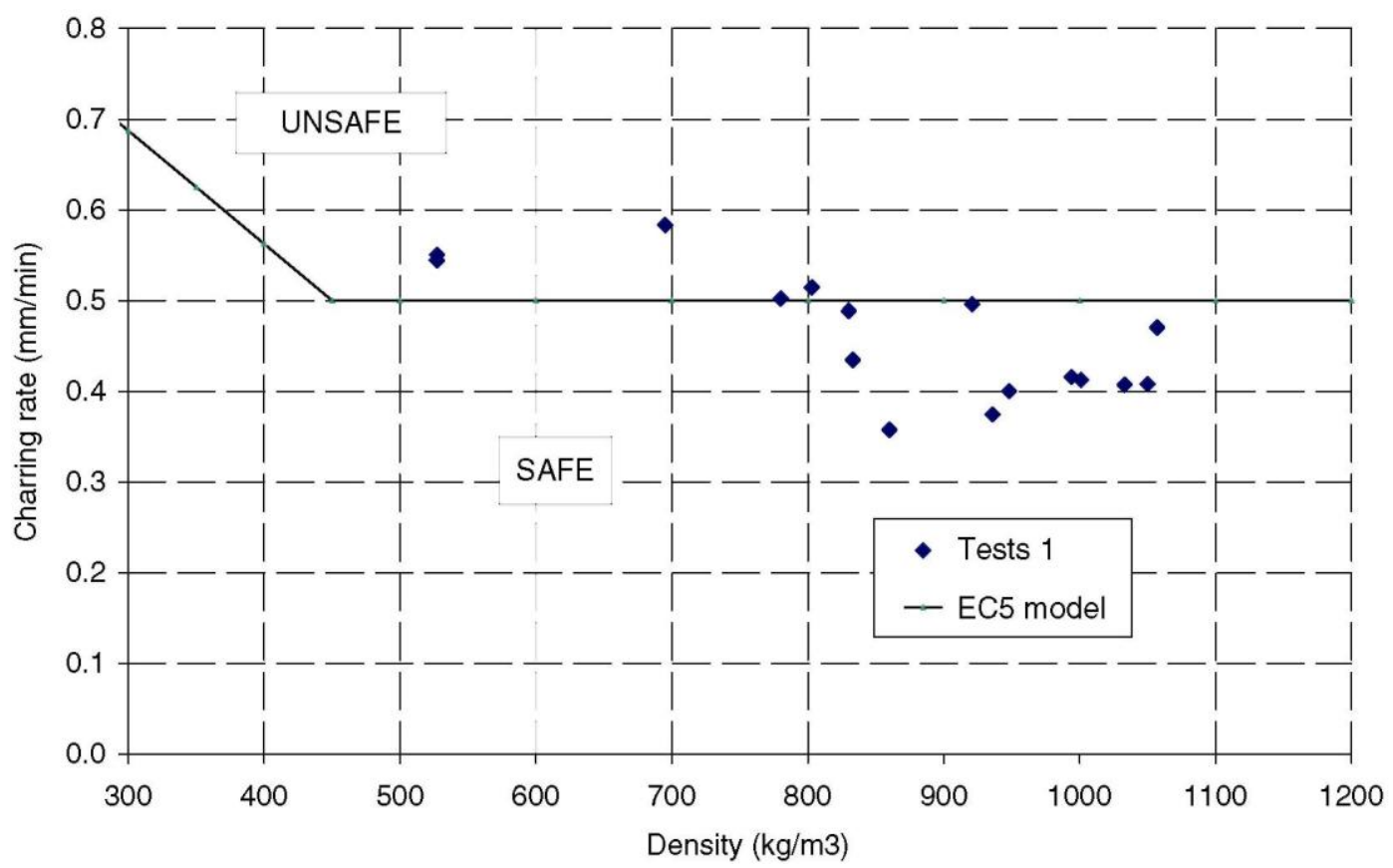

$\mathbf{x}$ 
Fig. 6. Comparison of test results with Australian standard for tropical species.

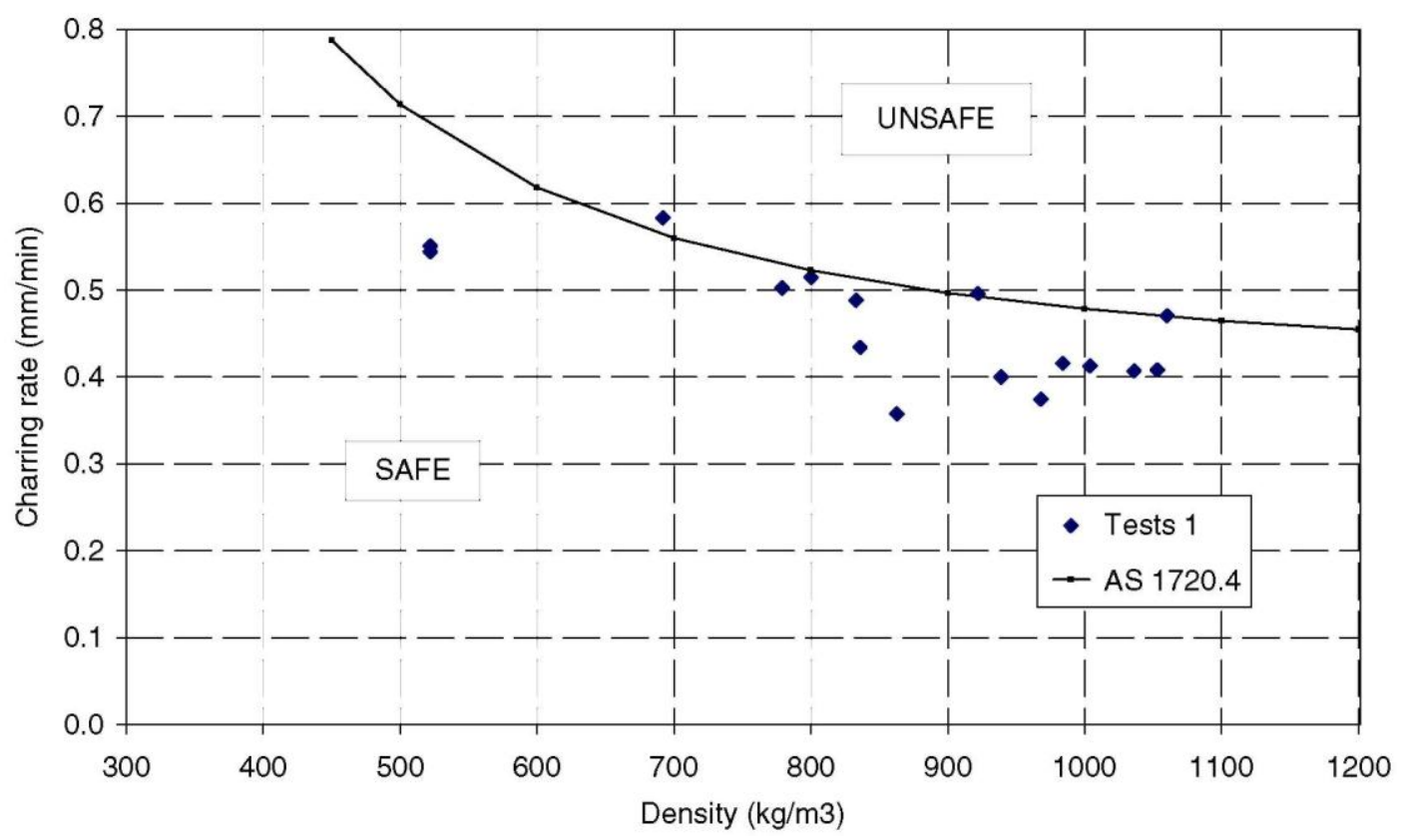

\subsection{White's model}

This model is more complicated for the following reasons:

- the relation between time and charred depth is not linear;

- the parameter $h$ in Eq. (2) depends on many physical characteristics;

- additional information is needed in order to evaluate the transport property $d$.

Estimates for the transport property $d$ have been suggested by White himself [14] based on values available in reference [12] (see Table 2).

By considering the parameters $p, \omega, c$ and $d$ in Eq. (3), values for $h$ have been obtained for each specimen.

Predictions of the charring time have been calculated with Eq. (2) based on the position of the thermocouple (charred depth) and then converted into a mean charring rate by dividing the charred depth by the charring time. Predicted mean charring rates based on White's model [5] are given in Table 3. If only tropical species are considered (test 5-20), the average for the ratio between the predicted value and the experimental value is 1.063 with a coefficient of variation equal to $15 \%$.

Fig. 8 shows for tropical hardwood specimens the ratio between the charring rate predicted by this model and the experimental value, plotted as a function of the density. The rather high variation can be seen on this picture. The dotted line formed by the linear regression of all the points shows that the safety level of the model varies with the density.

\subsection{Proposal for a new model}

The comparison of the experimental results obtained at the University of Liege with the results derived from the three models described in this paper shows that the models are not entirely satisfactory. Based on observations of these experiments, the following conclusions can be drawn.

- The Eurocode 5 model is safe and satisfactory for softwood species. For tropical hardwood species however, the model is unsafe for medium densities, but too conservative for high densities.

- The Australian code model is a more complex model (non-linear instead of bilinear). Furthermore it appears to be too conservative.

- White's formula is much more complicated than the two preceding models, as many physical characteristics that are not necessarily available to every day designers have to be evaluated. There is a significant variation between theoretical results and experimental results. 
Fig. 7. Comparison of test results with Australian standard for tropical species (2).

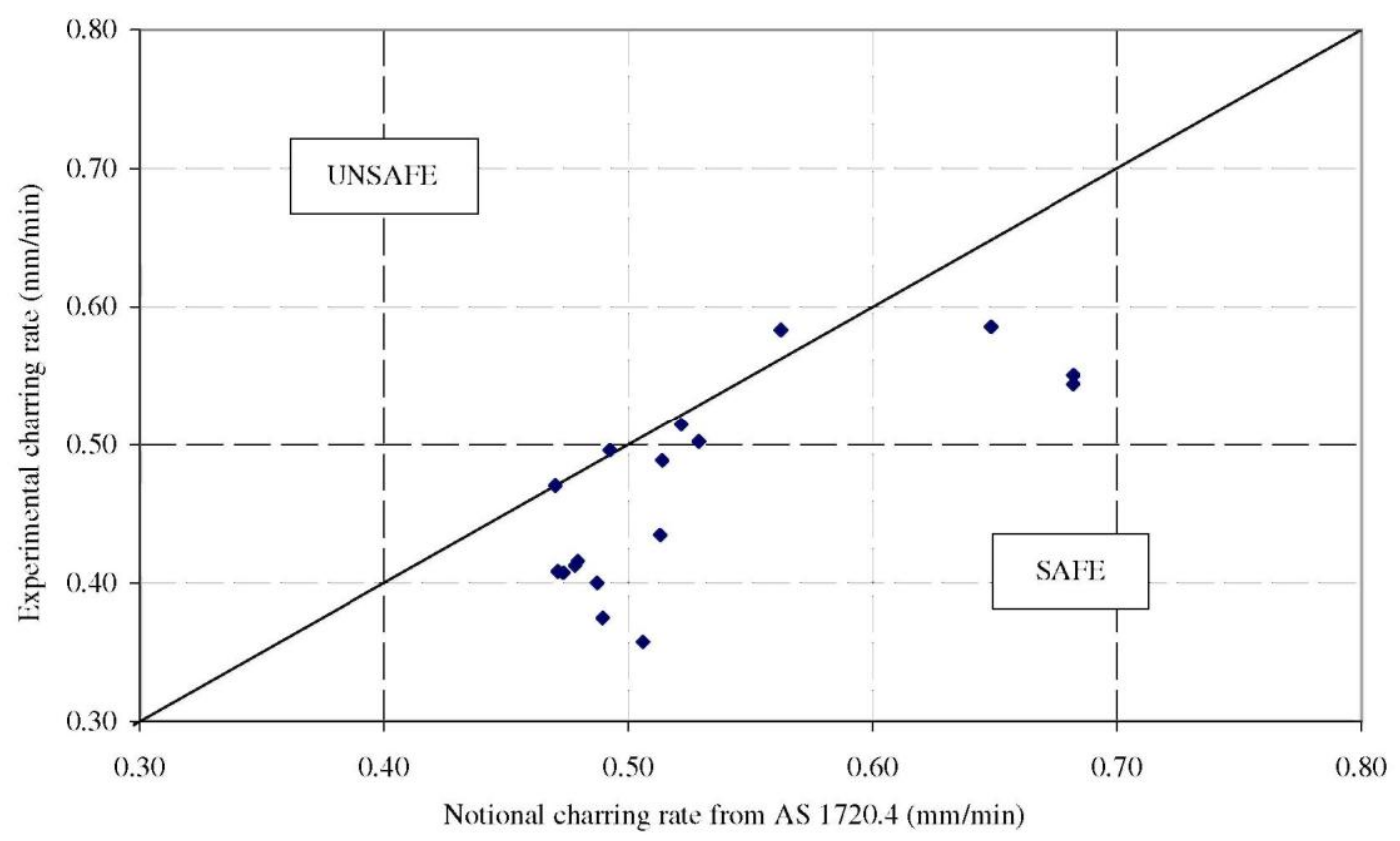

Fig. 8. Comparison of test results with predicted charring rates from White's model.

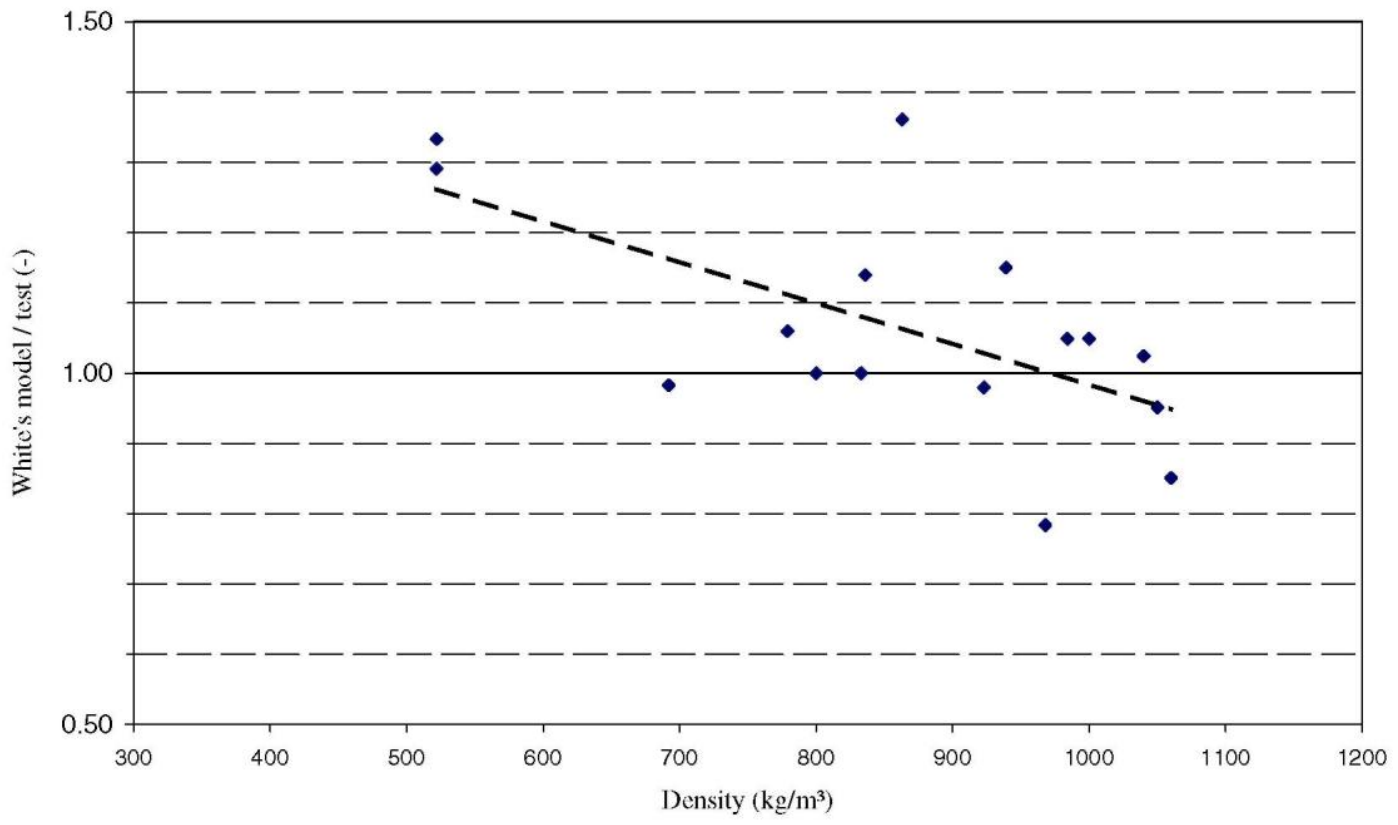

The model to be adopted here should avoid these drawbacks and provide a practical solution for design.

The proposed solution is shown in Fig. 9 on which each experimental result is represented by one point giving the charring rate as a function of the density. The linear regression of the experimental points is repre-

sented by a dotted line. The model adopted, noted "ULg model" on the figure, is almost parallel to this linear regression, at a slightly higher level. The equation of the proposed model is

$\beta=0.60-0.10 \frac{\rho-500}{300} \geqslant 0.40$. 
Compared to the linear regression line, Eq. (6) provides a slight safety margin. The average of the ratio model/test is 1.055 , very similar to the value obtained for the model of White. Because the coefficient of variation has been reduced from $15 \%$ for White's model to $10 \%$ for this model, the model proposed here is in fact slightly safer than White's model. With a normal distribution, the model of White should be on the safe side for $66 \%$ of the cases, whereas the proposed model should be on the safe side for $69 \%$ of the cases. An additional safety margin would in fact be introduced in practical design applications where the characteristic density of wood would be used, whereas the measured values have been used to derive the model.

Eq. (6) is based on simple coefficients, which makes it easy to remember and to use practically. The model has been limited to the value of $0.40 \mathrm{~mm} / \mathrm{min}$ for densities beyond $1100 \mathrm{~kg} / \mathrm{m}^{3}$ because no experimental test exists in this domain (such high densities are very rarely encountered).

Fig. 10 shows that the ratio ULg model/test is evenly distributed as a function of the density, which was not the case for White's model, see Fig. 8. It also shows that the scatter of the experimental values around the model is narrower than for White's model.

\section{Conclusions}

The main conclusions that can be drawn from this research study are:

1. The test set-up and the experimental procedure used in this study are suitable for assessing the charring rate of different timber samples.

2. The test results confirm that density of wood influences significantly the charring rate.

3. Experimental charring rates have been compared with the results derived from three models or empirical relations: Eurocode EC5-1.2 recommendation, Australian standard AS1720.4 relation and White's model. This comparison shows that the results, obtained from these three models are not entirely satisfactory.

4. A new bilinear model has been proposed in this study. The values proposed are acceptable for medium as well as for high densities.

5. Though the new model proposed constitutes an improvement it should be validated by additional experimental investigations.

Fig. 9. Model proposed for the variation of charring rate with density.

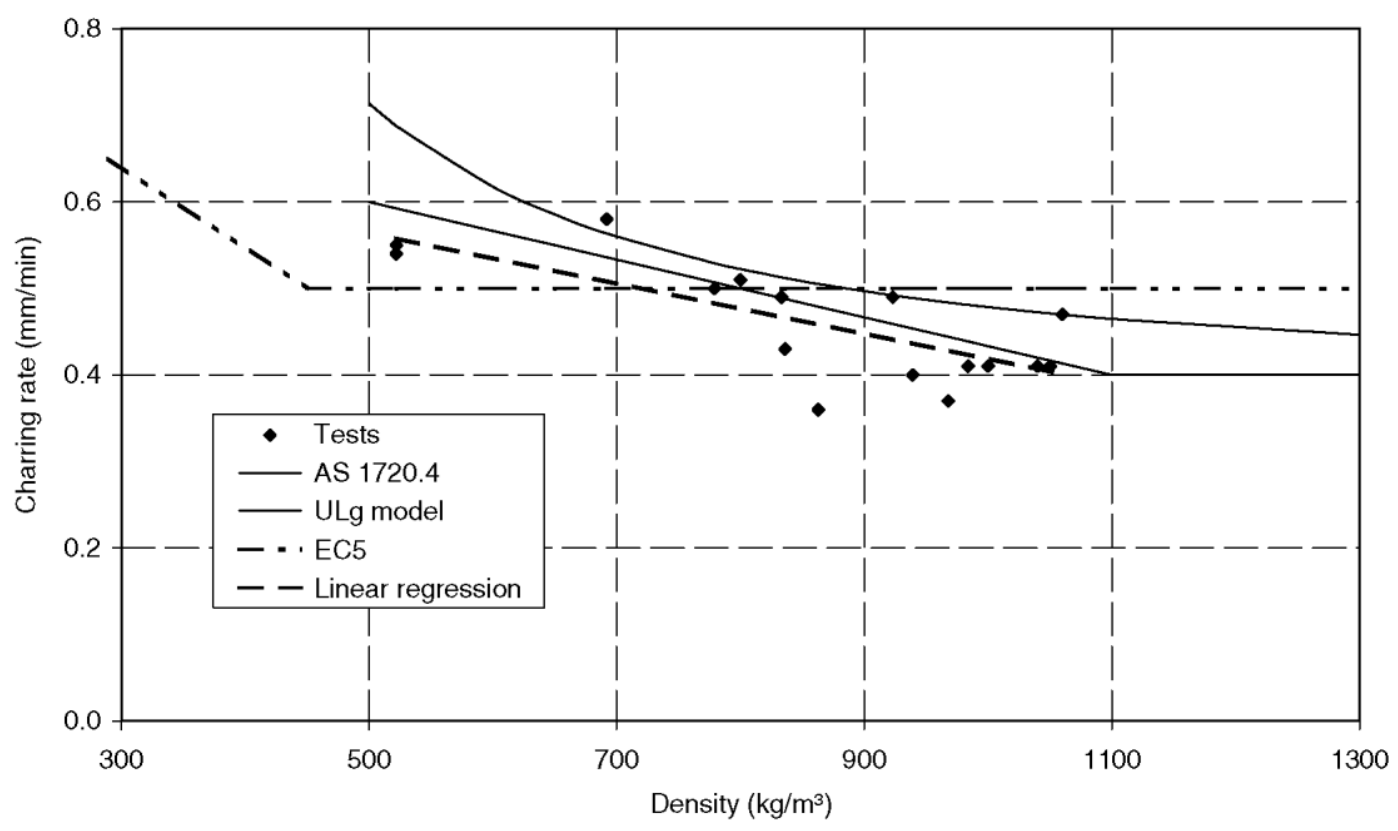


Fig. 10. Comparison of test results with the proposed model.

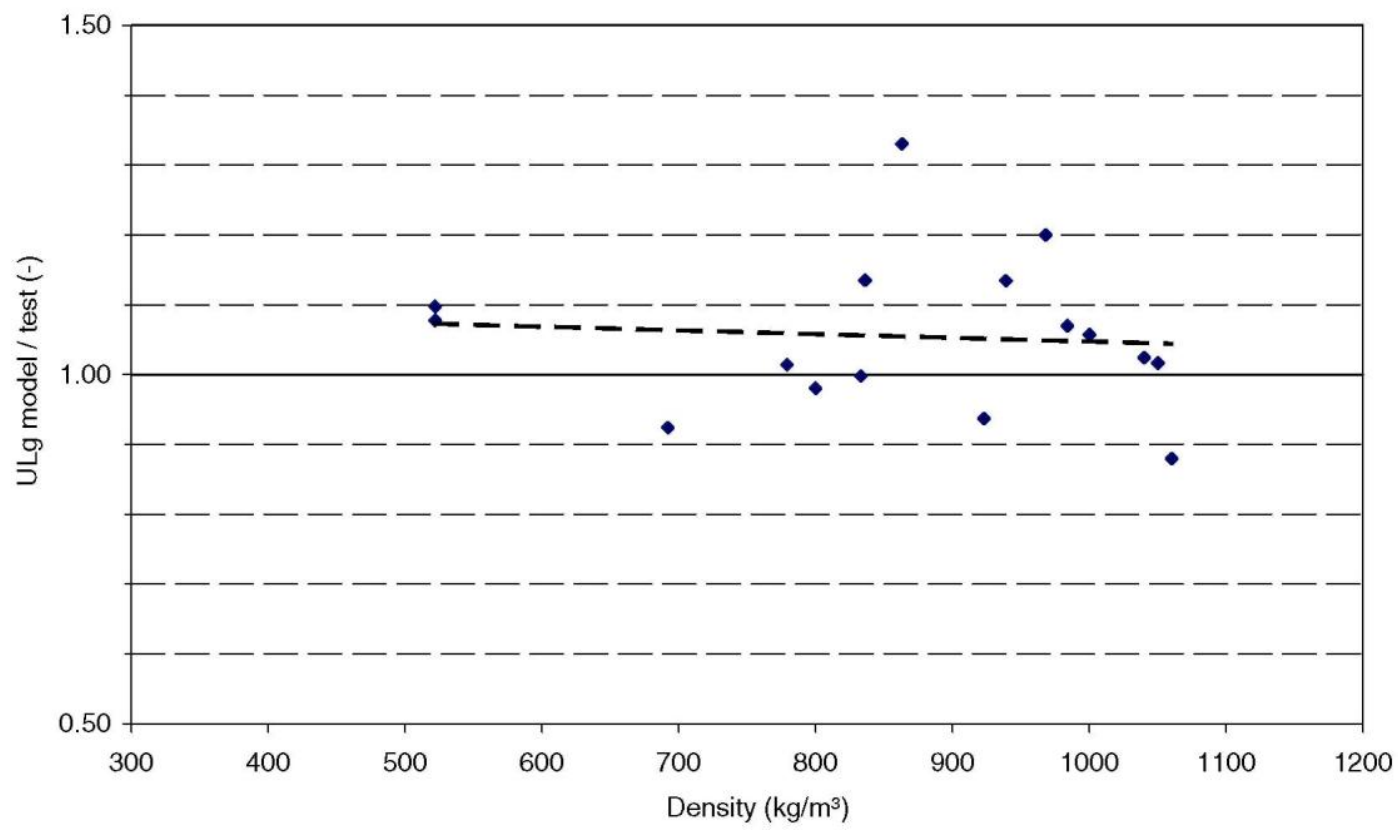

\section{Acknowledgements}

The authors gratefully acknowledge the Center of Cooperation for Development (CECODEL) and the Alice Seghers Foundation of the University of Liege, Belgium for their financial support of this research study. Special thanks are also addressed to Mery Bois Company for providing wood samples, to the joinery of the Technical Department of the University of Liege for sawing laminates, and to Biospeed Home Company for allowing temperature and charred depth measurements on one of their tested wall specimens. Advice and documents provided by Dr. R. White, Forest Products Laboratory, United States, are also acknowledged.

\section{References}

[1] ISO 834. Fire resistance tests - Elements of building construction. International Organization for Standardization; 1975.

[2] ASTM El19. Standard methods of fire tests of building construction and materials. Philadelphia (PA): American Society for Testing and Materials; 1983.

[3] ENV 1995-1-2. Eurocode 5: Design of timber structures - Part 1-2: General rules - Structural fire design. European prestandard; 1994.

[4] Schaffer EL. Charring rate of selected woods transverse to grain. Research paper FPL 69. Madison (WI): Forest Products Laboratory; 1967.

[5] White RH. Charring rates of different wood species. PhD dissertation, Madison University of Wisconsin, Madison (WI); 1988.

[6] White RH, Erik V, Nordheim EV. Charring rate of wood for ASTM El19 exposure. Fire Technol 1992;28(1).

[7] König J, Walleij L. One-dimensional charring of timber exposed to standard and parametric fires in initially unprotected and postprotection situations. Swed Inst Wood Technol Res 1999.

[8] Gardner WD, Syme DR. Charring of glued-laminated beams of eight australian-grown timber species and the effect of 13 mm gypsum plasterboard protection on their charring. N.S.W. Technical report no. 5. Sydney; 1991.

[9] Collier PCR. Charring rates of timber. Study report, Branz, New Zealand; 1992.

[10] Pun CY, Seng HK, Midon MS, Malik AR. Timber design handbook. FRIM, Malayan Forest Records no. $42 ; 1997$.

[11] AS 1720.4. Timber structures Part 4: fire resistance of structural timber members. North Sydney, Australia: Standards Australia; 1990. 
Published in: Construction and Building Materials (2005), vol. 19, iss. 5, pp. 376-386 Status : Postprint (Author's version)

[12] Agric. Handbook No. 607 Tropical timbers of the World.

[13] NBN 713-020. Fire resistance of building construction elements. Belgium Institute of Standardization; 1968

[14] White RH. Private communication 1992. 